\title{
Does Prophecy Cause History? Jeremiah 36: A Scroll Ablaze
}

\author{
Alice Deken, University of THE Free State
}

\begin{abstract}
In Jer 36, Jeremiah addresses a fundamental difficulty of prophecy raised by the climactic burning of his prophetic scroll by Jehoiakim on the eve of the Babylonian destruction of Judah. Would Jerusalem have been destroyed if Jehoiakim had not burnt the scroll prophesying the destruction of Jerusalem? Does the unrolling of metaphor determine history? Was it God's message of destruction presented in Jeremiah's prophecy that made Jehoiakim do it, condemning the king, the city and its people to destruction and exile? In this article, the implications of individual words are expanded to include Jeremiah, prophecy, history and God. Finally, it seems as if the prophecy and the event prophesied are caught up in the same inescapable loop of sequence and consequence.
\end{abstract}

KEYWORDS: Jeremiah 36; Jehoiakim; prophecy; exile; semantics.

\section{A INTRODUCTION}

This article is part of an ongoing project in which I consider the implications of a semantic reading of individual texts. In 2 Sam 21:1-141, a semantic analysis reveals a subtext that significantly undermines the overt meaning of the text. The story and the subtext come together when David finally recovers the bodies of Saul and Jonathan forburial. In Gen $14^{2}$, conventional history is subsumed in the depiction of a Babylonian metaphor derived from the four points of the compass, the implications of which are expanded by the historical events of the episode to include a "fifth" world empire. Here in Jer 36, individual words reverberate through this text, the Book of Jeremiah and the bible itself.

God sends His word to His people through the prophet Jeremiah. Ch. 36 of Jeremiah relates this prophecy to a particular historical event laid out in factual

* Submitted: 17/04/2017; peer-reviewed: 11/05/2017; accepted: 05/09/2017. Alice Deken, "Does Prophecy Cause History? Jeremiah 36 - A Scroll Ablaze," OTE 30 no. 3 (2017): 630-652. DOI: https://doi.org/10.17159/2312-3621/2017/v30n3a6

1 Alice Deken, "The Case of the Missing Crime 2 Samuel 21:1-14". Presented at a conference entitled "Rethinking Justice" 24 August. (Department of Theology, University of the Free State, South Africa, 2015).

2 Article under development. 
terms. Miller and Hayes tentatively date the episode to $603 \mathrm{BCE}^{3}$ when Nebuchadnezzar invaded Syria-Palestine (2 Kgs 23:34-24:2). The Judean king, Jehoiakim, and many people in Judah remained loyal to Neco of Egypt, a dependence that was violently opposed by Jeremiah and a minority in Judah. Perhaps on account of his Temple Sermon (Jer 7), Jeremiah is not allowed to appear in the temple on the day of a fast when the temple would be full. He sends his scribe Baruch, son of Neriah, to read his prophecy aloud.

Avigad has published three names which ... can be identified with personages mentioned in the Bible: Seriahu (son of) Neriahu, on a seal; Berchiahu son of Neriahu (Jer 36.32) the scribe, on a bulla; and Jerahmeel (Jer 36.26) son of the king, also on a bulla. With all due caution we support the probability of these identifications, and would add a fourth, contemporary name from our City of David group: Gemariahu son of Shaphan (Jer 36.10). ${ }^{4}$

Three names that have been verified archaeologically are found in ch. 36 of Jeremiah. This speaks to a specific interest in invoking historical reality in this chapter. What is the relationship between the historical detail and the translucent, shifting (shifty?) language of this chapter?

When Jehoiakim burns the scroll prophesying the destruction of Judah at the hands of "the people from the north" (Jer 25:9), he is both representing the prophesied destruction of Judah metaphorically, and translating prophecy into history by his action. His destruction of the scroll represents his rejection of prophecy and the word of God represented by the scroll, and renders the destruction of Judah inevitable. As the flames consume the scroll, the prophecy becomes a metaphor for the destruction of Judah. When Judah is destroyed, the metaphor is realized as history. The burning of the scroll as metaphor for the destruction of Judah becomes the evidence for the validity of God's word and the possibility of seeing the truth of His word in history.

\section{B JEREMIAH 36}

\section{$1 \quad$ Jeremiah 36:1}

The writer opens the chapter with an apparently standard opening, giving a specific date shortly before the Babylonian exile:

36:1

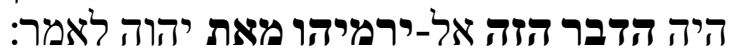

3 J. Maxwell Miller and John H. Hayes, A History of Ancient Judah and Israel (London: SCM Press, 2006), 462-468.

4 Yigael Shiloh, "A Group of Hebrew Bullae from the City of David," IEJ 36 (1986): 33. 
Jer 36:1: "In the fourth year of King Jehoiakim son of Josiah of Judah, this word came to Jeremiah from the LORD." ${ }^{5}$

However, the comparison with the opening of the preceding episode in ch. 35 is suggestive:

35:1 הדבר אשר-היה אל-ירמיהו מאת יהוה בימי יהויקים בןיאשיהו מלך יהודה לאמר:

Jer 35:1: "The word which came to Jeremiah from the LORD in the days of King Jehoiakim son of Josiah of Judah."

In ch. 35 , the date is less specific ("in the days of King Jehoiakim") than is the opening of ch. 36 ("In the fourth year of king Jehoiakim"), and the date is secondary to the nominal phrase ("The word which came") which opens the chapter. Chapter 35 provides a narrative background represented by a QATALverb, and the context ('In the days of Jehoiakim son of Josiah"), preceding the opening of the episode itself:

Qatal ... is not a narrative form but retrospective, since its function is to introduce the event which comes before the ensuing narrative. ${ }^{6}$

The point of the opening of ch. 35, as confirmed by the syntax, is that the first verse of the chapter offers "background" and is represented by QATALverbs prior to the beginning of the narrative proper demarcated with WAYYIQTOL at the beginning of 35:3. This is in contrast with the determination of the narrative foreground and the historical context in the corresponding verses in ch. 36. The effect is to identify the entire episode of ch. 35 as "generic," where the narrator is making a point that is independent of the historicity of the episode: Jeremiah offers wine to the Rechabites who have sworn never to drink wine

The command by Jonadab to his descendants had been carried out, as those present in the chamber saw with their own eyes when the Rechabites refused the wine. Yahweh, however, has spoken to the covenant people continually ... but they have not so much as bent an ear. The point is clear: the sons of Jonadab carried out their father's command, while the covenant people have not heeded Yahweh and the commands he has given them. ${ }^{7}$

Chapter 35 makes a moral point in relation to the historical events narrated in ch. 36. This chapter functions as background to ch. 36; the syntax reflects this.

5 Translations of the text are from the JPS Bible Translation: JPS Hebrew-English Tanakh (Philadelphia: The Jewish Publication Society, 1999), 1102-1105.

6 Alviero Niccacci, The Syntax of the Verb in Classical Hebrew Prose (Jerusalem: Sheffield Phoenix Press, 1990), 36.

7 Jack R. Lundbom, Jeremiah 21-36, AB (New York: Doubleday, 2004), 580. 
The syntax of the first verses of chs. 35 and 36 reflects a comparative foregrounding of the specific historical events of ch. 36 represented by the opening WAYYIQTOL, in relation to the unhistorical, moral example represented by a small group of people conforming to a specific way of life.

The implications of the Rechabites' refusal of wine in obedience to an oath is a metaphor of the historical context of the events of ch. 36. Metaphor and history serve the same purpose. Both demonstrate that history and metaphor exist as reflections of the word of God, to whom history, detached from time, is a metaphor for His word, and the word of God is a metaphor for history. Our failure to honor the moral implications of our covenant with God represented metaphorically by the Rechabites is represented in the historical, i.e. demonstrably true, events of this chapter.

Allowing for variations in style and objective, the expression representing a specific regnal year ויהי בשנה occurs regularly in the Deuteronomic History: 1 Kgs 15:25; 2 Kgs 22:1; 1 Kgs 22:41; 2 Kgs 15:23; 2 Kgs 17:6; Jer 46:2; Jer 51:59. In the hands of this writer, the function of שנה as a noun, "year,"8 includes the possibility of its being understood as a verb, "change." The root has already been used in the book of Jeremiah, in the sense of "to change the direction of (political) action" in the text:

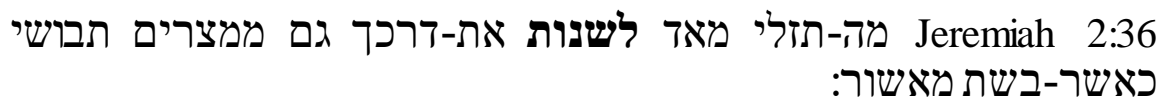

Jer 2:36: "How you cheapen yourself, By changing your course! You shall be put to shame through Egypt, Just as you were put to shame through Assyria."

At the end of the book and with the word "shame" still ringing in our ears, the root is used to refer to Jehoiakim's change out of prison clothes when he is allowed a place as a deposed king at the table of "evil-Merodach of Babylon":

\section{2:33}

Jer 52:33: "He removed his prison garments ..."

From the use of the root to refer first to political upheaval in ch. 2, to a single historical incident during a year of the reign of Jehoiakim in ch. 36, and then to a change of clothes in ch. 52, the duration implied by the term becomes increasingly shorter. Rather than a representation of daily life measured in years in relation to the eternal and unchanging nature of God to which mankind

8 Francis Brown, Samuel R Driver, Charles A Briggs, The Brown-Driver-Briggs Hebrew and English Lexicon (Massachussetts: Hendrickson Publishers, 2004), "שנה," 1040. 
accedes through obedience to his laws, the root is used to mark the inexorable force of the onset of historical time:

Malachi 3:6: "For I am the LORD - I have not changed; and you are the children of Jacob - you have not ceased to be."

Thus, the first verse of this chapter hints at the iterative nature of the apparently unique historical event that is represented by Jehoiakim's burning of Jeremiah's scroll. That Jehoiakim, the king who burns the prophecy, seems to be personally responsible for the destruction of Jerusalem, is qualified by the repetitive, cyclic, impersonal, inevitable nature of the action. This repetitive and cyclic action, representing the responsibility of the people for their own destruction, just as - under different circumstances - they would be responsible for their own salvation - is represented by the motifs of marriage, adultery and separation between God and his people, but above all by the subversion of literal meaning in the words of the prophet.

The reference to Jehoiakim as the son of יאשיהו includes a reference to the verb for "despair" "יאש and the definition of his role in history as "king of Judah" ידה includes "give thanks" or "praise." Between "despair" and "praise" Jehoiakim's personal name and title include the circumstances of every individual in Judah. The desperation of his position is represented by the destruction of Jerusalem. His rejection, as king of "Judah," of the option of "thanks" implicit in his title, represents an act of hubris matched by the apostasy of the king's "despair" in the face of prophecy offering redemption, and God's fickle people.

This distinction between the choices made by the people, and their position in relation to God, is again alluded to in the phrase:

הדבר הזה ... Jeremiah 36:1

One function of making the expression specific, firstly by the use of the article and secondly by the use of the demonstrative pronoun, is to suggest that the writer is pretending to ward off the more general references, which are in fact invoked by his awareness of the implications of his terms, represented by puns on the word דבר11. The noun refers to "word", quintessentially the "word of God"; in this text represented by the prophet Jeremiah

Jeremiah 1:2

Jer 1:2: "The word of the LORD came to him in the days of King Josiah ..."

$9 B D B$, , 384.

10 BDB, “"ידה" 392.

11 BDB, “דבר" 182. 
The root letters דבר also refer to "pestilence"12, an implication that was invoked earlier in the book:

14:12 אינני רצם כי בחרב וברעב ובדבר אנכי מכלה אותם: Jeremiah

Jer 14:12: “.. I will exterminate them by war, famine, and disease.”

The "word" of God and the consequences of apostasy - "pestilence," suggested here by the root דבר, parallel the "despair" and "praise" that are suggested by Jehoiakim's name and title. This time, the contrast is implicit in the use of the same root instead of two different roots united by the king's name and title - the relationship between cause and effect is tightening.

Jeremiah himself invokes an association between his own destiny and that of Judah, when he reminds us that ידה the root of "Judah," and רמה the root of "Jeremiah" both also mean "cast, shoot"13, implicitly identifying his own destiny with that of Judah:

אל-14 ערכו על-בבל סביב כל-דרכי קשת ידי אליה אל-תחמלו אל-חץ ...

Jer 50:14: "Range yourselves roundabout Babylon, All you who draw the bow; Shoot at her, don't spare arrows" (also Jer 4:29).

Additionally, רמה is the root for a noun meaning "deceit" or "treachery"14:

Jeremiah 5:27 ככלוב מלא עוף כן בתיהם מלאים מרמה על-כן גדלו ויעשירו:

Jer 5:27: "As a cage is full of birds, So their houses are full of guile; That is why they have grown so wealthy."

Jeremiah, a prophet of God who is fiercely protective of Judah and treasonably opposed to the course of political action that the king has embarked upon in favor of Egypt, is directly identified with the welfare of Judah in a pun on the names of Judah and Jeremiah, through his calling by God. His calling is in respect of his appointment as a prophet of God and entails that the sovereign authority of the land take him at his "word," apparently the "word of God." That "word" avails itself of a number of very different options in terms of what it means, here, representing the "word" - the means by which it transmits its message, as "pestilential," even as it claims to represent the means of salvation. At the same time, just as Jeremiah's name invoked his identification with

12 BDB, “דבר" 184.

13 BDB, "רמרד" 941.

14 BDB, “רמה" 941. 
Judah, so his name also represents, attested to by Jeremiah himself, "treachery" and "deceit"15:

Jeremiah 9:5 שבתך בתוך מרמה במרמה מאני דעת-אותי נאם-יהוה:

Jer 9:5: "You dwell in the midst of deceit. In their deceit, they refuse to heed $\mathrm{Me}$ - declares the LORD."

When Jeremiah himself, as a prophet of God, purports to represent the antithesis to the implications of his own name, what are Jehoiakim and the people of Judah to believe?

The term מאת (Jer 36:1) is used in Jer 9:1 for a wife deserting her husband. In the context of ch. 9, the metaphorical "wife" is Judah and her promiscuity and fickleness in relation to her husband (God) are a consistent motif in the Book of Jeremiah. Its invocation here in ch. 36 in a context ostensibly about Jehoiakim, suggests that this particular episode, about Jehoiakim's disaffection from God, includes, in his role as king, the disaffection of the people of Judah from their God. Jehoiakim's actions make manifest the role that the people themselves have played in the sequence of events culminating in the destruction of Jerusalem. The destruction of Jerusalem is prefigured in the particular sequence of historical events represented by a king burning the scroll containing the prophecy of his own destruction, but its roots seem to lie in the ever-returning, iterative apostasy and betrayal of God by His people.

\section{Jeremiah 36:2}

In the second verse of the chapter, Jeremiah is given the instruction that triggers the events of this chapter:

\section{קeremiah 36:2

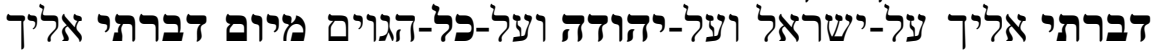

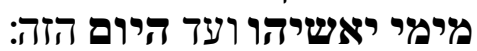

Jer 36:2: "Get a scroll and write upon it all the words that I have spoken to you - concerning Israel and Judah and all the nations - from the time I first spoke to you in the days of Josiah to this day."

The identification of the theme of this chapter as apostasy is hinted at in the use of the verb קחירל - לקח in the instructions given to Jeremiah, long used in the sense of "to take in marriage"'16 (Gen 24:4;27:46; $1 \mathrm{Kgs} \mathrm{4:15).} \mathrm{Throughout}$ the book, Jeremiah invokes metaphors of marriage and adultery to represent the relationship between the people of Judah and their God (Jer 2:2). God instructs Jeremiah to write the scroll that will represent God's grounds for the destruction

15 BDB, “רמה" 16 "רקח", 541. 
of Jerusalem and the Babylonian exile. In invoking a married relationship between God and his people, the verb לקח also points at the breakdown of that relationship. Jehoiakim's destruction of the prophetic scroll functions as a metaphor for the breakdown of the relationship, matrimonial and semantic, between God and his people. This destruction of the scroll representing the history of the relationship between God and his people must result in the destruction of Jerusalem and the exile of its people, whose occupation of the land is a metaphor for their covenant with God (Deut 11:8) whom they have betrayed. The destruction of the scroll not only prefigures the destruction of Jerusalem, but is a necessary part of the sequence of events.

The theme of iteration or repetition recurs in the reference to the סֵפֶ of v. 2:

$$
\text { קeremiah 36:2 }
$$

This reference represents the fundamental conflict in this chapter as that between God's view of history as cyclical - the noun מגלה is derived from the גלל meaning "roll, roll up or along":

Isaiah 34:4

Isaiah 34:4: "The heavens shall be rolled up like a scroll."

This rolling repeats itself in relation to the eternal, unchanging God, and the linear sequence of cause and effect experienced by man in history. This is represented by the historical events of the chapter: Jeremiah's prophecy and Jehoiakim's burning of the scroll following the Babylonian victory over the Egyptians at Carchemish in 605 BCE:

36:1

Jer 36:1:“In the fourth year of King Jehoiakim son of Josiah of Judah"

This precise representation of the date would suggest that the events of the year are unique and that they are in fact being precisely delineated in this chapter in order to record them for posterity. The conflict between these two modes of relating to events is represented by the scroll itself, in which a linear, sequence of historical events are represented, which are kept in the form of a roll (מגלה) which itself suggests that these events are not unique and already in the past, but repetitive and ongoing. This conflict is resolved by the historical working out of the metaphor in the prophecy as written in the scroll.

Jeremiah is called on by God to imitate Moses, who had to write the tablets of the Ten Commandments:

Exodus 34:1: "The LORD said to Moses: 'Carve two tablets of stone like the first." 
The relationship between the Mosaic tradition representing the covenant with God and the occupation of the Promised Land as long as they continued to obey him is "repeated" at the end of this chapter, when Jeremiah has to rewrite the scroll that has been destroyed, just as Moses had to rewrite the tablets of the Ten Commandments. Jehoiakim's burning of the scroll convicts him by his own actions of the charges he stands accused of in the scroll. The act of burning the scroll is intended by Jehoiakim as a symbol of contempt for the prophet and his words, denying any allegiance to the God whose "pestilential" words Jeremiah claims "deceitfully" to represent, and rejecting the historical claims that the scroll makes "circularly." Once the predicted destruction of Jerusalem has been accomplished, the act of burning the scroll by Jehoiakim is, as a result of its fulfillment when the city burns: a symbol of the truth of prophecy; the validity of the scroll; the apostasy of the people of Judah; the hubris of their king, and the supremacy of God whom Jeremiah quotes.

The prioritizing of the form of the physical scroll and its being burnt as a prophecy of the destruction of Jerusalem confirms the contents of the scroll, which prophesied that Jerusalem would be destroyed by fire. This analogy, where the burning of the scroll stands for the burning of Jerusalem, is echoed in the treatment of the prophet himself. The prophet has already early in the book been the subject of intimations of the scribe as an "instrument" of prophecy, rather than a messenger:

\section{Jeremiah $1: 7$}

Jer 1:7: “... But go wherever I send you And speak whatever I command you."

The calling into question of the nature of prophecy and the role of the prophet as an instrument, rather than a mouthpiece of God, is illustrated by the death by burning of prophets accused of false prophecies by the King of Babylon, himself an instrument of God's plan to save Judah:

Jeremiah 29:21-22: "Thus said the LORD of Hosts, the God of Israel, concerning Ahab son of Kolaiah and Zedekiah son of Maaseiah, who prophesy falsely to you in My name: I am going to deliver them into the hands of King Nebuchadrezzar of Babylon, and he shall put them to death before your eyes. 22 And the whole community of Judah in Babylonia shall use a curse derived from their fate: 'May God make you like Zedekiah and Ahab, whom the king of Babylon consigned to the flames!'”

As instruments of prophecy, the deaths of Ahab and Zedekiah are understood by Jeremiah to testify to the validity of his prophecy as opposed to that of his opponents, and to the sovereignty of his God. All the while, one implication of these events is that the false prophets were designated by God to be examples 
of the consequences of adultery "17, literally when they sleep with other women, and metaphorically when they promote the service of other gods. At the same time, the adulterous prophet becomes a metaphor for Judah, God's adulterous bride. ${ }^{18}$ Significantly, Jeremiah/God in ch. 29 has already testified to this relationship between history and metaphor which emerges as the means by which God orders the relationship between cause and effect in this text.

This consciousness that our actions are completely subject to God's will, make the act of writing represent both Jeremiah's willingness to subject himself to anything that God may choose to impose on him (he may no longer be around to testify to the contents of the scroll himself), and confirms the writing of the scroll as the primary function of his prophetic career. The scroll itself is the prophetic instrument. Whether or not Jeremiah dies, his writings will testify to the prophecies and to God's supremacy over our destinies. As instrument, the prophet shares in the fate that befalls the nation; he is not exempted from that fate as a messenger would be. His own life testifies to the events that he is prophesying. Thus, the biographical sections of the text are integral to the message that God, not the prophet, is sending. Fundamental to that biography is the prophet's own insecurity in relation to the unreliability of the mechanism by means of which he has to relay his message:

Jer 1:6: "I replied: Ah, Lord GOD! I don't know how to speak,"

Just as this text records the events leading up to the destruction of the scroll, so the recorded events of the prophet's own life represent an analogy for the circumstances that resulted in the breakdown of the relationship between man and God. However, this awareness of the shifting relationship between words and their meaning, as a metaphor for the relationship between man and God, has already been invoked by Moses in the record of his own call:

Exodus 4:10: "But Moses said to the LORD, 'Please, O Lord, I have never been a man of words, either in times past or now that You have spoken to Your servant; I am slow of speech and slow of tongue."”

In the same manner that the death of the "false" prophets confirms the historical implications of "adultery," so the inability of God's prophets to realize meaning in speech confirms our inability to escape the necessity of repeating history "roundly," to our own death and destruction.

The root גלל invokes a number of themes and motifs that seem relevant to Jeremiah's analysis of the events leading up to the destruction of Jerusalem. As a noun, in addition to the reference to the roll of a scroll, it can also refer to a heap of "rubble" (Jer 9:10). This image is reiterated at the end of the book, this

\footnotetext{
17 Jer 29:23.

18 Jer 2:2; Jer 5:7.
} 
time in reference to Babylon (Jer 51:37). This semantic correlation between Babylon and Judah echoes the method that was used to establish a semantic link in the pun between ידה which established a thematic tie between Jeremiah and Judah.

Underlying the use of the root גל is the meaning of "dung." It is not used explicitly in this sense in this book - the implication is made explicit in the book of Kings:

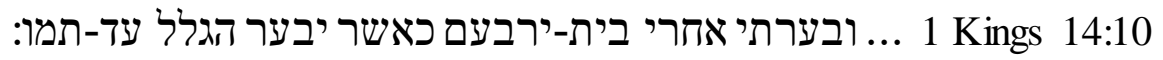

1 Kings 14:10: “ ... I will sweep away the House of Jeroboam utterly, as dung is swept away."

Ascribing at least some common heritage to both the Deuteronomistic and Jeremianic discourse firmly places the parenetic prose within the late seventh through mid-sixth centuries, the same period that saw the composition of Deuteronomy and the Deuteronomistic History. ${ }^{19}$

However, the use of the root further suggests the ball of dung rolled by the beetle, representing (tenuously, and if so, offensively) the dung-beetle and hence the Egyptian scarab, invoking all of Jeremiah's bitterness at Jehoiakim's loyalty to Egypt and his disloyalty to God and Judah in the face of the threat represented by Babylon.

Thus the root is used in the sense of "wheel" in

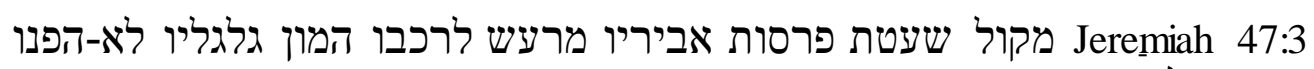
אבות אל-בנים מרפיון ידים:

Jer 47:3: "At the clatter of the stamping hoofs of his stallions, At the noise of his chariots, The rumbling of their wheels, Fathers shall not look to their children Out of sheer helplessness."

In the rumbling of the chariot "wheels", all the implications of the root are combined in this representation of an invading army: the inexorable roll of the invading forces; the roll of the book of prophecies; the ruin of the House of Jeroboam as a heap of dung, remaining loyal to Egypt but not to God; and the invocation of Babylon as a "mountain" ultimately to be destroyed by God, but not in order to save Jerusalem from destruction.

The root is used again in the sense of "roll" in:

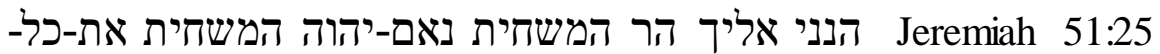

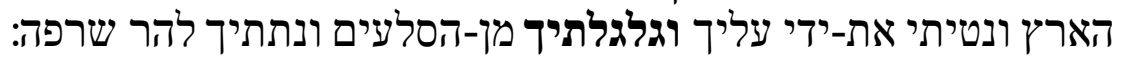

19 Mark Leuchter, Josiah's Reform and Jeremiah's Scroll (Sheffield: Sheffield Phoenix Press, 2006), 9. 
Jer 51:25: "See, I will deal with you, O mountain of the destroyer ${ }^{20}$ declares the LORD - Destroyer of the whole earth! I will stretch out My hand against you And roll you down from the crags, And make you a burnt-out mountain."

The imagery associated with the root גלל proceeds full circle in the Book of Jeremiah, from the roll of a scroll recording the prophecies of Jeremiah and, by implication, the word of God, to an image of destruction, which includes the entire earth. Even the use of the "cephulim" invokes the iterative cycle of apostasy, destruction and forgiveness, fundamental to the looming catastrophe.

This second verse of the chapter is marked by repetitions of the roots: יום These three roots, each occurring twice or three times in this same verse, mark the fundamental conflict between man's experience in and of the world, and eternity in relation to God. Earlier in the book, Jeremiah invoked the capacity of words to represent truth as well as falsehood - part of his ongoing polemic against false prophecy - but undermining the process, is the meaning of the words that he himself uses to offer redemption to the people. Jeremiah himself uses the root in its sense of "plague" or "pestilence":

\section{4:12 אינני רצים כי בחרב ובערב ובדבר אנכי מכלה אותם: ... אeremiah}

Jer 14:12: “... I will exterminate them by war, famine, and disease.”

In this verse, God is threatening his people with the same word that Jeremiah is offering for their salvation. Words (דבר), represented by the intercession of the prophet, will not save them. The people (and the reader) are trapped between the opposing implications of דבר: truth or falsehood, obedience or pestilence.

The root כל is regularly used by Jeremiah to mean "whole, all": 27:7 ועבדו אתו כל-הגוים ואת-בנו ואת-בץ-בנו ...

Jer 27:7: "All nations shall serve him, his son and his grandson."

Derived from the verb meaning "complete, perfect," 21 Jeremiah ironically uses the same root to suggest both the subjugation of "all" the nations under Babylon as a consequence of their disloyalty, and at the same time represents God as "complete," "perfect" - eternal, and with the capacity to exempt them from the consequences of their actions. The word is also the root of כלה, "bride,"22 which is already well-established as a metaphor for union (or disunion) with God.

20 Jack R. Lundbom, Jeremiah 37-52, AB (New York: Doubleday, 2004), 458: “’(O) Mountain of the Destroyer,' here a metaphor for the city of Babylon".

21 BDB, "כלל", 480.

$22 B D B$, , "כלה" 483. 
The word יום refers very specifically to man's experience of the world, as a sequence of "days." One of those days has just placed Judah under Babylonian rule and the "days" to come, according to the prophet, will see the destruction of Jerusalem and the Babylonian exile. In this context, the three roots כל ,דבר and יום are revealed as deeply ambiguous constructs, representing prophecy or falsehood, God or gods - and history, the consequences of the choices made or coerced into by God's prophetic word. The writer of Jeremiah presents the conditions of the people as analogous to the position of Jehoiakim prior to his burning of the scroll. Prophecy, God and Babylon represent the terms of Jehoiakim's condition.

The phrase מגילת-ספר occurs only four ${ }^{23}$ times in the biblical text, and two of these occurrences are in Jer 36. At the end of the chapter, when Jeremiah and Baruch are instructed to rewrite the scroll which Jehoiakim defiantly burnt prior to his kingdom going up in flames as predicted in the scroll, God no longer uses the phrase מגילת-ספר, but refers only to מגילה:

$$
\text { שוב קח-לך צמלה אחרת ... שeremiah 36:28 }
$$

Jer 36:28: "Get yourself another scroll ..."

A necessary effect of the use of the construct in קחז-לך is to bind the noun and the verb closely together, making it clear that the object of the writing is the faithful recording of all of the words of God. The intention seems to be to specify the verifiability, the absolute truth of the recorded words, so that just as there is grammatically no separation between the noun and the verb, so there is no question in the mind of the reader between the truth and the contents of the scroll. The "word" represents both the means of salvation and the grounds for distrust by the people of the "word." The mechanism that the prophet uses to record the word of God מיום דברתי in order to witness to the truth thereof represents the reason why the message will not be heard. It is this capacity of the text to turn the reader into a witness that is invoked by the writing of all of the words of God in the scroll. The burning of the scroll is itself an act of the kind of hubris committed by the king and his false prophets that led to the prophetic injunctions describing the destruction of Jerusalem in the first place.

2 Samuel 11:14 ויהי בבקר וכתב דוד ספר אל-יואב וישלח ביד אוריה:

2 Samuel 11:14: "In the morning, David wrote a letter to Joab, which he sent with Uriah."

Here the meaning of ספר is specifically a "letter." This letter is a deceitful message sent by David in order to cover another act of deceit. The usage here in 2 Sam invokes the implication that messages are normally transmitted in a ספר.

23 Abraham Even-Shoshan, A New Concordance of the Bible (Israel: The New Book, 2000), 619. 
The noun, employed ironically here as the mechanism used by God to support and inform his people, is taken advantage of by their God-elected king.

The word ספר is used in the sense of "message," "remembrance," "letter" in the bible ${ }^{24}$, emphasizing its origin as a written "message" from someone else. At the end of Jer 36, the writing of the text has lost its implication of "message" or "letter" (from God) and has become instead a scroll מגילה for record-keeping, for recording history (repeatedly). Its contents and their relation to the history to which it testifies will ultimately witness to the truth of God's word and the sanctity of his prophet, but God cannot prevent the enactment of the "message" burnt into history by Jehoiakim's brazier. After the burning of the scroll, there is no longer a message.

This sense that God is not the active agent in the events that follow is confirmed in the change of the verb וכתבת in v. 2 to וכתב in v. 28. In v. 2, the verb with the waw-consecutive expresses what Juoun-Muraoka ${ }^{25}$ calls the "nuance of succession" which becomes static, represented grammatically by the use of the stative infinitive at the end of the chapter. At the beginning of the chapter, the scroll is both a record of the prophecies that God "sent" to Jehoiakim through his elected prophet, and also a program of action to change the historical sequence of events. This is denied by Jehoiakim, and the succession of events that would lead to salvation as dictated by the scroll would never take place.

This sense of "succession" invoked grammatically is additionally emphasized by three instances of the word יום in the same verse. This succession of "days"26, representing opportunities to demonstrate obedience to God, is the means by which mortal man overcomes the limitations of his existence and accedes to unity with God, immortality and timelessness. It invokes the steady approach of the day of reckoning when our accumulated actions of the preceding days culminate one "day" in the predicted/predictable historical conclusion.

24 DCH, "ספר", 189, "rarely means book (as literary composition)."

25 Paul Jouon and Takamitsu Muraoka, A Grammar of Biblical Hebrew (Roma: Gregorian \& Biblical Press, 2009), 1191 . "The writer is fairly often free to express the nuance of succession or not; thus we find Jr 36.2 'Take a scroll, you shall write on it

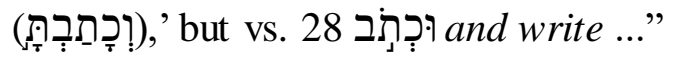




\section{Jeremiah 36:3}

\section{Jeremiah 36:3}

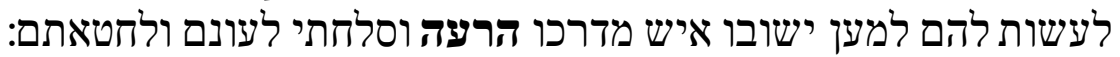

Jeremiah 36:3: "Perhaps when the House of Judah hear of all the disasters I intend to bring upon them, they will turn back from their wicked ways, and I will pardon their iniquity and their sin."

is the name of a river in Babylon and (after a bit of shuffling with semantics) one of the four rivers of Paradise. ${ }^{27}$ As God warns of the disasters he intends to visit on Judah, he invokes the nature of the disaster in a reference to the name of the river in the direction from which the disaster comes.

It may be straining credulity to suggest that an adverb meaning something like "perhaps, peradventure" is deliberately invoked to suggest that the people of Judah are resigning their claim to salvation and paradise in the face of an enemy from "the north." אולי is used 45 times in the HB in the sense of "perhaps," and 2 times in the sense of the river "Eulaeus." My suggestion that its use here in ch. 36 in Jeremiah includes an allusion to the river in the North is not reflected in the concordance. It was already an old-fashioned word at the time of the writing of Jeremiah and of its 45 occurrences, 12 are in Genesis. ${ }^{28}$ I suggest that the term is used deliberately to represent Babylon, and perhaps even to invoke an allusion to Paradise. Jeremiah is prophesying that the people of Judah are again giving up their claim to eternal life in favor of a relationship of servitude to Babylon. At the end of the book, the term is again invoked in relation to Babylon, this time mockingly:

\section{אולי 5emiah 51:8 פתאום נפלה בבל ושבר הילילו עליה קחו צרי למכאובה אולי תרפא: - (1:8}

Jer 51:8: "Suddenly Babylon has fallen and is shattered; Howl over her! Get balm for her wounds: Perhaps she can be healed."

Just as ostensibly "positive" words are exploited for their subversive implications in this text, negative words are mined for their positive implications.

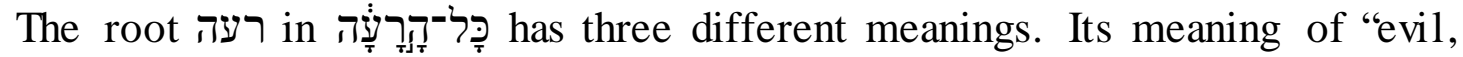
injury, misery" 29 is reflected here in v. 3. The implication of "pasture, tend, graze" 30 is reflected in its use in the book of Jer in ch. 3:

27 According to Wikipedia Contributors, "The Karkheh or Karkhen," online: https://en.wikipedia.org/wiki/Karkheh_River, this is "Known as the Gihon - one of the four rivers of Eden/Paradise to the Bible and as the Choaspes in ancient times; also called Eulæus; Hebrew: אולי Ulai."

28 Even-Shoshan, Concordance, 25a.

29 BDB, “רעה", 949.

30 BDB, "רעה", 944. 
Jeremiah 3:15 ונתתי לכם רעים כלבי ורעו אתכם דעהוהשכיל:

Jer 3:15: “And I will give you shepherds after My own heart, who will pasture you with knowledge and skill."

The meaning of "associate with"31 from which the noun "friend" or "companion" are derived is represented in Jer 6:21. Like דבר puns on "pasture, tend, graze." The motif of God as a shepherd, implying that the people of Judah are his flock, frequently appears in the text and interposes itself between the text and its meaning to the reader. In v. 36.3, God represents himself as a shepherd at the same time as he is threatening them with disaster. Just as words are both a means of betrayal represented by false prophets, but in the words of the text by ambiguities which subvert the implications of every verse, and the mechanism for salvation in the text, so God represents the means of salvation in the same word רעה that he uses to represent their doom.

\section{Jeremiah 36:4}

את כל-דברי יהוה אשר-דבר אליהו את-ברוך בירן-מגלת-ספרה וכתב ברוך מפי ירמיהו

Jer 36:4: "So Jeremiah called Baruch son of Neriah; and Baruch wrote down in the scroll, at Jeremiah's dictation, all the words which the LORD had spoken to him."

Jeremiah summons Baruch in the same verb קרא that God uses to summon the devastation with which he threatens Judah, while the people persist in their apostasy (Jer 1:15). This is also the same verb that God instructs Jeremiah to use while he is prophesying (Jer 11:6). The same root yields the image of a partridge invoked by Jeremiah in one of his own prophecies. The suggestion is that the worship of false gods represents an unjust accumulation of wealth, represented perhaps by an unjustified confidence in a future that the false god cannot possibly represent:

\section{Jeremiah 17:11 קרא דג ולא ילד עשה עשר ולא במשפט ...}

Jer 17:11: "Like a partridge hatching what she did not lay, so is one who amasses wealth by unjust means."

The image of a caged bird as a metaphor for deceit and betrayal was also invoked by Jeremiah at 5:27 (quoted). Like רמה for Jeremiah, a verb that is elsewhere in the text associated with the word of God and with prophecy, is here used as invoking an ambiguous image.

Throughout the text, the means of prophecy, the "word" is undermined and subverted as the most significant statements in the text attest to meanings,

31 BDB, “רעד", 945. 
implications and invocations that contradict the stated intent of their usage. Just as Jehoiakim and the people of Judah do not know what to make of it, so Jeremiah himself is aware of the shortcomings of his message:

Jeremiah 1:6:

Jer 1:6 'I replied: ‘Ah, Lord GOD! I don’t know how to speak, For I am still a boy."

To which God replied:

\section{1:8 אל-תירא צפעיהם כי-אתך אני להצלך נאם-יהוה: Jeremiah}

Jer 1:8: "Have no fear of them, For I am with you to deliver you declares the LORD."

Jeremiah's increasing awareness of the implications of his prophetic words might call his attention to the fact that the root פנה also means "turn."32 He has good reason to be concerned that rather than delivering God's message, he is God's message, an implication that has already been raised in this chapter, just as God's assurances now (with hindsight) invoke differing implications for Jeremiah's prophetic career.

\section{Jeremiah 36:15-1733}

ביאמרו אליו שב נא וקראנה באזיפו ויקרא ברוך 36:15

באזעיהם:

Jer 36:15: 'They said, 'Sit down and read it to us.' And Baruch read it to them."

Having read the scroll aloud in the Temple, Baruch is asked to read it privately to the king's scribes. Twice in the same short verse, the root This gives the writer the opportunity to interject a number of cynical tropes into the representation of Baruch's audience.

In Jer 6:10, ears are described as "uncircumcised." 34 This includes the suggestion that the listeners do not or will not participate in the covenant with God - that their anxiety to listen is qualified by their inability to obey their God.

32:10 ואכתב בספר ואחתם ואעד עדים ואשקל הכסף במאזנים

Jer 32:10: "I wrote a deed, sealed it, and had it witnessed; and I weighed out the silver on a balance."

32 BDB, “פנה", 815.

33 Due to space constraints I cannot present the entire chapter here.

34 BDB, "רזא", 24. 
This reference to money that occurs in the same root in Jer 32:10 is also implied by the use of the root קרא in v. 4 in this chapter, suggesting that the ability to amass money was ascribed to the worship of false gods, whose promises were a riches that could never be realized. The repetition of the root in this verse reiterates the implication that the anxiously listening scribes are precluded from participation in the covenant with God and that they worship false gods - and listen to false prophets!

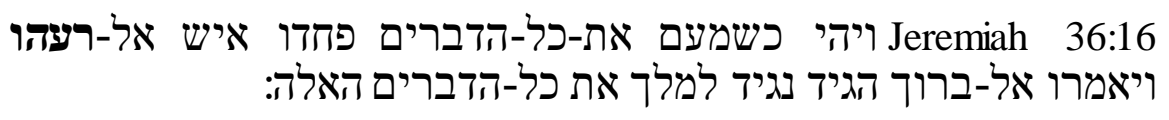

Jer 36:16: "When they heard all these words, they turned to each other in fear; and they said to Baruch, 'We must report all this to the king."'

Ironically, the scribes are afraid of what they have heard, but they fail to register the necessary religious awe, being "uncircumcised," which the invocation of the term implies. In their distress they turn to the people sitting with them, their "friends" characterized by the root רעה which includes the root for "evil." The scribes are afraid of what they have heard but are not in awe of the power of God, and they rely on each other, their "friends" to support them in their wrongdoing.

\section{Jeremiah 36:17 ואת-ברוך שאלו לאמר הגד-נא לנו איך כתבת את-כל-

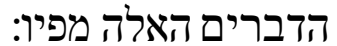

Jer 36:17: "And they questioned Baruch further, 'Tell us how you wrote down all these words that he spoke."

They question Baruch in the verb שאל, invoking in their own terms שול "hell" characterized in Ezek 32:21 as the abode of the "uncircumcised." Even while they are questioning him, and granting him credence in their own view, they are invoking the conditions of their destruction.

\section{Jeremiah 36:23}

Jeremiah dictates the scroll to Baruch and Baruch reads out the scroll on a fast day, while Jeremiah is still in "detention" and when all the Judeans will be there (Jer 36:6). Baruch first reads the scroll out in public at the temple and is then called to read the scroll to the king's scribes. They report the contents to the king. Jehudi is told to read the scroll out to the king:

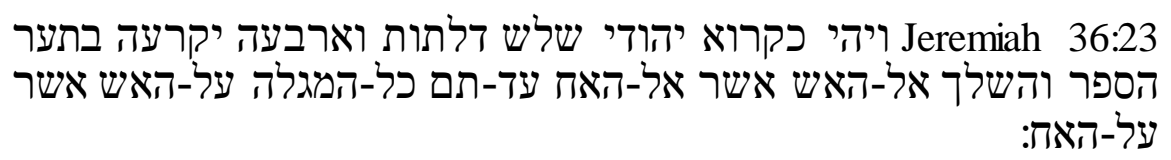

Jer 36:23: "And every time Jehudi read three or four columns, the king would cut it up with a scribe's knife and throw it into the fire in 
the brazier, until the entire scroll was consumed by the fire in the brazier."

The text uses the hapax legomenon ${ }^{35}$ דלתות for the columns in the scroll. ${ }^{36}$ The effect (predictably in this text) is to invoke wordplay ${ }^{37}$ :

אם-הומה היא נבנה עליה טירת כסף ואם-דלת היא Song of Solomon 8:9 נצור עליה לוח ארז:

Song of Solomon 8:9: "If she be a wall, We will build upon it a silver battlement; If she be a door, We will panel it in cedar."

This usage confirms the BDB's suggestion that the noun is used to represent an "easily accessible woman" - a woman whose door is always open, invoking the motifs of adultery and going in pursuit of foreign gods, which this chapter and the Book of Jeremiah as a whole represents as the fundamental reason for the destruction of Jerusalem and the Babylonian Exile. Hicks suggests that the connection between "door" and "column of writing" was originally derived from the fact that wooden boards coated with a thin layer of wax were also used for writing, and that these must have suggested the idea of a column of writing that looked like a "door." Thus, the text uses the word for boards in spite of the fact that this particular text is written on a leather roll and bears no relationship to the shape or materials of a "door." I infer that this rare form is deliberately used in order to suggest the opening of both the "gates of a city" and the "doors" of the houses of Jerusalem prior to its destruction. The two meanings referenced by the context here, invoke distinct images - the one the domestic, private home being crudely broken into by an invading army, the other the security of the city, comprising people, things, lifestyle, society and security, destroyed by the inability of the "delet" to hold back the invaders. Similarly, the columns of text are destined to fail the people when Jehoiakim tosses them into those flames which will subsequently destroy Jerusalem and its Temple. The additional implication of an "easily accessible woman" invokes the image of Jerusalem and its people as a bride to God and as a harlot (Jer 2:20), equally if not entirely to blame for these events. Represented in this single reference are the crime, worship of other gods; the punishment, the destruction of the city and the homes of everyone in it; and the means - invasion.

35 Even-Shoshan, Concordance, 266b, includes this verse in the word list for "doors." 36 R. Lansing Hicks, "DELET and MEGILLAH: A Fresh Approach to Jeremiah XXXVI," VT 33/1 (1983): 48. "Bearing the sense of a column of writing, delet is here not only a hapax legmenon in the Masoretic Text but is rare in the whole corpus of published Hebrew writings and inscriptions."

37 BDB, "דלת", 195, "1. Door of house; 2. Door of room; 3. Gates of city; 4. ... of column of MS. (from shape) Jer 36:23; fig of easily accessible woman, Ct 8:9". 
The word may also include (with only a small stretch of the imagination) a pun on the nearby root דלה, "branch, bough."38 Jeremiah repeatedly refers to the nation as a branch of various plants including the olive:

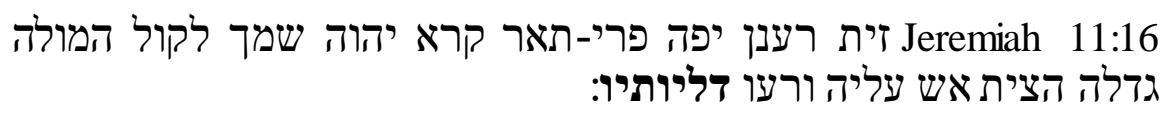

Jer 11:16: "The LORD named you 'Verdant olive tree, Fair, with choice fruit.' But with a great roaring sound He has set it on fire, And its boughs are broken."

The olive tree is the pre-eminent symbol of settlement. It takes approximately seven years for a tree to bear fruit; this implies a significant investment in time to establish. The fact that this olive tree bears fruit implies an extended period of settlement and the social, economic and military organization that goes with it. The invocation here of the "branch" echoes the many explicit references to olive trees and the branches of various orchard trees throughout the text, and the wood of the "delet," in association with the implicit reference to the people of the city (in the following paragraph). This invocation represents a gradually accumulating account of the nature of their losses, should the prophecies invoked by God fall on uncircumcised ears. It seems appropriate that this kind of "accounting" should be reiterated in the chapter where the scroll is burnt in a gesture of contempt for the prophet and his God.

The fact that the king uses a "scribe's knife" בתער הספר re-invokes the word which is the one that has been severed from the prophetic scroll between the beginning of this chapter and its' end. The word ספר also includes meanings of "to recount" (narrate, tell) and "to count" (number), ${ }^{39}$ and the writer succeeds in combining the implications of both as he "narrates" their "losses" in the cumulative imagery of impending doom which, after the end of this chapter, can no longer be withheld. The use of the imperfect instead of the participle in v. 23, both of which express "duration" but of which the imperfect expresses "progressive duration," 40 expresses "actions ... which were repeated in the past, either at fixed intervals or occasionally." 41 The effect of the repetitive action in the "progressive" tense creates a mood of the inexorable passage of time in this verse, already invoked in the loaded references to יום in the second verse of this chapter. The imperfect is followed by the infinitive construct imposing "the notion of exact convergence of the two actions whereby the one action is immediately followed by the other." 42 As the pages of the scroll are thrown into the

\footnotetext{
38 BDB, "דלה", 194.

$39 B D B$, "ספר", "דרי"

40 Gesenius, $G K C, 107$ d p. 315 , quoting Driver.

41 Gesenius, GKC, 107e p. 315.

42 Jouon and Muraoka, Grammar, 166m, p. 589.
} 
flames, so the days of impending doom converge on Jerusalem, threatening not only the king and his supporters but every man and woman in the city. The word that Jeremiah uses for the fire in the "brazier" is the word אח, also "brother." Our own lives and those of our brothers are at stake.

\section{Jeremiah 36.28}

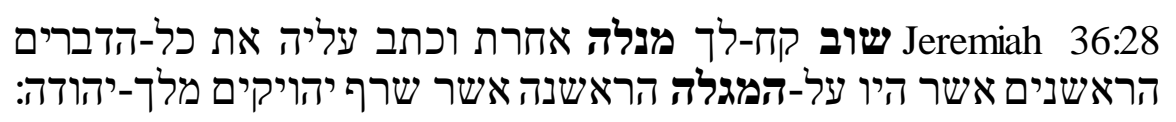

Jer 36:28: "Get yourself another scroll, and write upon it the same words that were in the first scroll that was burned by King Jehoiakim of Judah."

The theme-word of the Book of Jeremiah is pre-eminently שוב. It occurs in various forms 90 times in the text, compared to (22 times) adding up to $57^{43}$ mentions of "fire" or "burning." $B D B$ defines שוב as "turn back, return" 44 and the sense included in Jeremiah's usage generally implicitly or explicitly implies a "turning back" from apostasy, or repentance. ${ }^{45}$ However, the specific sense in the context of this verse is one of iteration. Time and again Judah strays, and time and again she repents and is forgiven (Jer 31:19). In an ironic use of the verb שוב, God tells Jeremiah to again write down the prophecies, without the salving sense of "message" or "reminder" represented by the expression מגילת-ספר. Jeremiah writes a scroll for recording the prophecies that testify to the validity of prophecy; the prophet's status as elected by God and God's position as the God of Judah. This too has an ironic sense in that Jeremiah's predecessor was burnt for prophesying falsely:

the most interesting mention of death by burning in the bible is the execution of the false Jewish prophets mentioned in the letter sent by Jeremiah to the first wave of exiles in Babylon (Jer 29:1-23). ${ }^{46}$

As such, the scroll may stand as a record both of Jeremiah's prophesying to save himself from the charge of false prophecy, and of the fire that he is prophesying for Jerusalem. Conveniently, for direct speech the verse is in the imperative and in the perfect tense. The switch to direct speech gives the writer the

43 Even-Shoshan, Concordance, 1118, 1209.

44 BDB, "שוב", 996: 1. Turn back; 2. Return, come or go back; 3. Return unto; 4. Of dying, of revival from death; 5. Return to leader, king, turn, return; 6. Spiritual relations: a. turn back from God, = apostatize, b) turn away, c) turn back to God, d) repent.

45 Jeremiah 3:1: "[The word of the Lord came to me] as follows: If a man divorces his wife, and she leaves him and marries another man, can he ever go back to her (הישוב)? Would not such a land be defiled? Now you have whored with many lovers: can you return to me (ושוב)? - says the Lord.”

46 Paul-Alain Beaulieu, "The Babylonian Background of the Motif of the Fiery Furnace in Daniel 3," JBL 128/2 (2009): 278. 
excuse to avoid the "narrative tense" (ויהי), implying sequence and progression for the rest of the chapter. ${ }^{47}$ There is to be no further progression in the narrative, just the iterative working out of events foretold proving that the prophecy is true. Jehoiakim attempts to burn the scroll, to assert his authority over the people as King of Judah and master of his environment, but Jeremiah simply rewrites the scroll - with additions. The "additions" now reflect the fact that Jehoiakim burnt the first scroll, confirming the destruction of Jerusalem and including the Babylonian Exile. Even as he tries to reassert his own conception of his circumstances on the events, the words of the scroll mock his efforts.

\section{CONCLUSION}

Unlike 2 Sam 21:1-14 and Gen 14, there appears to be no semantic sub-text to this chapter. In prophecy and in the word of God, metaphor and history are united. In Jer 36, the prophetic text is both prophecy and a metaphor for prophecy in that the simultaneity of the historical event and its metaphor reflects the word of God. This semantic analysis both allows me to question the implicit agenda of this text, and to compare the results with other passages that I am considering on the same basis.

This semantic analysis grants access both to the individual units of the text - the words, and to the largest structures of this text, Jer 36, the book of Jeremiah as a whole, and the Bible itself, in relation to which this text exists. Jehoiakim's burning of Jeremiah's prophetic scroll gains its significance first from its historical context as prelude to the destruction of Jerusalem by the enemy from "the north" (Jer 1:14; 4:6; 46:24), but then also in its context in this text. Jeremiah struggles with the problem of whether or not the fact that it is prophecy makes it history that gives the actors no choice in their course of action, relating the historical context of the text to the nature of God. In the same way, the relationship between prophecy and the word of God is analyzed in terms of the images that are invoked by the language of the text. God's word is found to be transparent, predictive and true while at the same time being deceptive and misleading. These discontinuities in our understanding are themselves a metaphor for our relationship with God presented metaphorically and actually, as a marriage. Prophecy does not cause the destruction of Judah, but the destruction of Judah demonstrates that the word of God is true. The king of Judah who cuts up the prophecy and throws it into the fire metaphorically represents the people of Judah who fail to listen to God's word and rather pursue other gods. It is their actions that set the events of this text in motion.

47 Jouon and Muraoka, Grammar, 118d. "This feature of succession characteristic of the wayyiqtol construction becomes particularly evident when biblical writers, when they do not want to express succession, deliberately avoid wayyiqtol and replace it with w-..qatal." 


\section{BIBLIOGRAPHY}

Beaulieu, Paul-Alain. "The Babylonian Background of the Motif of the Fiery Furnace in Daniel 3." JBL 128/2 (2009): 273-290.

Brown, Francis, Samuel R. Driver, and Charles A. Briggs. The Brown-Driver-Briggs Hebrew and English Lexicon. 12th ed. Massachusetts: Hendrickson Publishers Inc, 1906.

Clines, David J. A. A Dictionary of Classical Hebrew. London: Sheffield Phoenix Press, 2007.

Deken, Alice. "The Case of the Missing Crime: 2 Samuel 21:1-14." Paper presented at a conference titled "Rethinking Justice" hosted by the Department of Theology, 24 August, (University of the Free State, South Africa, 2015).

Even-Shoshan, Abraham, ed., A New Concordance of the Bible. 7th ed. Israel: The New Book, 2000.

Gesenius, Wilhelm. Gesenius' Hebrew Grammar. Edited by Emil Kautzsch. Translated by Arthur E. Cowley. 28th ed. New York: Dover Publications Inc., 1909.

Hicks, R. Lansing. "DELET and MEGILLAH: A Fresh Approach to Jeremiah xxxvi." VT 33/1 (1983): 46-66.

Juoun, Paul and Takamitsu Muraoka. A Grammar of Biblical Hebrew. 2nd ed. Translated by Takamitsu Muraoka. Roma: Gregorian and Biblical Press, 2009.

Leuchter, Mark. Josiah's Reform and Jeremiah's Scroll: Historical Calamity and Prophetic Response. 1st ed. Sheffield: Sheffield Phoenix Press, 2006.

Lundbom, Jack R. Jeremiah 21-36. AB. 1st ed. New York: Doubleday, 2004. . Jeremiah 37-52. AB. 1st ed. New York: Doubleday, 2004.

Miller, J. Maxwell and John H. Hayes. A History of Ancient Judah and Israel. London: SCM Press, 2006.

Niccacci, Alviero. The Syntax of the Verb in Classical Hebrew Prose. 1st ed. Translated by Wilfred G. E. Watson. Sheffield: Sheffield Phoenix Press, 1990.

Shiloh, Yigael. "A Group of Hebrew Bullae from the City of David." IEP 36 (1986): 16-38.

The Jewish Publication Society. JPS Hebrew-English Tanakh.2nd ed. Translated by The Jewish Publication Society. Philadelphia: The Jewish Publication Society, 1999.

Alice Deken, MA. Research Fellow: Department of Theology, University of the Free State. Address: Amstelveen, Netherlands.e-mail: alice.deken@gmail.com. 